\title{
Comparison of biological and chemical properties of arable and pasture Solonetz soils
}

\author{
${ }^{1}$ R. K. GAngwar, ${ }^{2 *}$ M. MaKÁdi, ${ }^{1}$ M. Fuchs, ${ }^{1}$ Á. CsOrba, ${ }^{1}$ E. Michéli, ${ }^{2}$ I. DeMETER, \\ ${ }^{1} \mathrm{~T}$. SZEGI \\ ${ }^{1}$ Department of Soil Science and Agricultural Chemistry, Faculty of Agriculture and \\ Environmental Sciences, Szent István University, Gödöllő \\ ${ }^{2}$ Research Institute of Nyíregyháza, IAREF, University of Debrecen, Nyíregyháza
}

\begin{abstract}
Soil samples were collected from salt-affected soils (Solonetz) under different land uses, namely arable ( $\mathrm{SnA})$ and pasture $(\mathrm{SnP})$, to investigate the effects of land use on microbiological [basal soil respiration (BSR), microbial biomass carbon (MBC), dehydrogenase activity (DHA) and phosphatase activity] and chemical properties [organic carbon (OC), humic ratio (E4/E6), $\mathrm{pH}$, electrical conductivity (EC), ammonium nitrogen $\left(\mathrm{NH}_{4}-\mathrm{N}\right)$, nitrate nitrogen $\left(\mathrm{NO}_{3}-\mathrm{N}\right)$, available forms of phosphorus $\left(\mathrm{P}_{2} \mathrm{O}_{5}\right)$, potassium $\left(\mathrm{K}_{2} \mathrm{O}\right)$, calcium $\left(\mathrm{Ca}^{2+}\right)$, magnesium $\left(\mathrm{Mg}^{2+}\right)$, sodium $\left.\left(\mathrm{Na}^{+}\right)\right]$and on the moisture content.

The results showed that the two sites, $\mathrm{SnA}$ and $\mathrm{SnP}$, were statistically different from each other for all the microbiological and chemical parameters investigated except $\mathrm{Na}^{+}$and moisture content. Higher values of MBC $\left(575.67 \mu \mathrm{g} \mathrm{g}^{-1}\right)$, BSR $(9.71$ $\mu \mathrm{g} \mathrm{CO}_{2} \mathrm{~g}^{-1}$ soil $\left.{ }^{-1}\right)$, DHA (332.76 $\mu \mathrm{g}$ formazan $\mathrm{g}^{-1}$ day $^{-1}$ ) and phosphatase activity $\left(0.161 \mu \mathrm{mol} \mathrm{PNP} \mathrm{g}{ }^{-1} \mathrm{hr}^{-1}\right)$ were observed for the SnP soil. Great heterogeneity was found in $\mathrm{SnP}$ in terms of microbiological properties, whereas the SnA plots showed more homogeneous microbiological activity due to ploughing. $75.34 \%$ of variance was explained by principal component one ( $\mathrm{PC} 1)$, which significantly separated SnA and SnP, especially on the basis of soil MBC and $\mathrm{P}_{2} \mathrm{O}_{5}$. Moreover, it was concluded that the pasture land $(\mathrm{SnP})$ was microbiologically more active than arable land (SnA) among the Hungarian salt-affected soils investigated.
\end{abstract}

Keywords: salt-affected soil, land use, soil microbiology, chemical properties, heterogeneity

\section{Introduction}

Salt-affected soils are one of the most characteristic soil formations in the Carpathian Basin. The total geographical coverage of these soils in Hungary is approximately $10 \%$, which is an unusually high value (SZABOLCS \& VÁRALLYAY 1978). Comprehensive and detailed knowledge on the chemical, mineralogical, physical, hydraulic and botanical properties of salt-affected soils and on their classification, reclamation and amelioration has been published since the 1800's (e.g. HERKE 1949; ARANY 1956; SZABOLCS \& JASSÓ 1959; ÁBRAHÁM \& BOCSKAI,

Postal address: MAKÁDI MARIANNA, Research Institute of Nyíregyháza, IAREF,

University of Debrecen 4400 Nyíregyháza, Westsik Vilmos utca 4-6.

E-mail:makadim@gmail.com 
1971; TótH et al., 1998; VÁRALLYAY 1999; TóTH \& VÁRALLYAY 2001; TóTH et al., 2001; KUTI et al., 2002; SZENDREI \& TÓTH 2006; BALOG et al., 2014; TóTH et al., 2015). However, the microbiological properties of salt-affected soils and the consequences of salinization and sodification processes were not widely investigated in Hungary (BIRÓ et al., 2002; MUCSI et al., 2017). An increase in some microbial groups was reported by BIRÓ et al. (2002) at higher salt content (10 $\left.\mathrm{g}^{-1}\right)$. KHALIF et al. (2005) investigated the effect of increasing salt content on soil enzyme activities in the rhizosphere of bean varieties, while a few papers mainly reported the microbiological properties of salt-affected lakes (BORSODI et al., 2005, 2007; FELFÖLDI et al., 2009; SOMOGYI et al., 2009; SZABÓ et al., 2004) or focused on plant-microbe interactions in salt-affected soils (FÜZY et al., 2003; FÜZY et al., 2008; SZILI-KovÁCS et al., 2017). MUCSI et al. (2017) investigated the catabolic activity of soil samples taken from four sites representing different vegetation types, using the MicroResp method.

The research published in the international literature focused on the effects of soil reclamation, and the amelioration of salt-affected soils. According to SUMNER (2000) the chemical properties of soils are affected by the presence of high soluble salt concentrations, which alter the soil osmotic potential and adversely affect soil microbial communities and enzyme activities (REITZ \& HYNES, 2003; SARDINHA et al., 2003). The negative impact of salinity on the size and activity of soil microbial biomass and biochemical processes was also reported by TRIPATHI et al. (2006) and YUAN et al. (2007). Microbial activities (microbial biomass C, microbial biomass $\mathrm{N}$ and basal soil respiration) are reduced under high salinity, resulting in a reduction in the rate of organic matter decomposition and the mineralization of $\mathrm{C}, \mathrm{N}$ and $\mathrm{P}$ (IWAI et al., 2012). The activity of dehydrogenase and phosphatase in the soil was also reported by BATRA \& MANNA (2007) and JING et al. (2013), respectively, to be considerably reduced by an increase in soil salinity.

Various specific indicators of soil microbial activity have been proposed to assess soil status (BASTIDA et al., 2008; LUCAS-BORJA et al., 2011; HEDO et al., 2015), including the activity of several enzymes specifically related to the cycles of nitrogen, phosphorus, carbon and sulphur (urease, alkaline and acid phosphatase, $\beta$ glucosidase and arylsulphatase, respectively) and general microbial indicators such as dehydrogenase activity and soil respiration.

The effects of land use on soil quality, soil functions and ecological processes due to the modification of the physical, chemical and biological properties of soils were reported by POUYAT et al. (1995) and BENDING et al. (2002). Similarly, BALOTA et al. (2003) reported that less intensive management results in higher microbial activity. Microbial activity plays a key role in the ecological function of soils and in maintaining the ecological quality and productivity of soils (GROVER et al., 2011; IWAI et al., 2012). Improper land management practices may cause environmental stress in cultivated fields, such as a loss of soil nutrients, soil organic carbon and microbial activity, compaction, erosion and salinization (EUROPEAN COMMISSION, 2007).

ÁBRAHÁM \& GINÁL (1967) investigated the effects of about 15 years of cultivation on the chemical properties of soils of former Solonetz pasture. TóTH et 
al. (2009) and TóTH \& FARKAS (2010) found higher $\mathrm{CO}_{2}$ emission and biological activity on pasture land than on arable land in the case of Mollic-Cambisol and Chernozem soil types in Hungary, but overall little literature is available in Hungary on the effects of land use on soil microbiological properties.

The aim of the study was to investigate and compare the microbiological and chemical properties of Solonetz soils under different land uses, and thereby to provide relevant information for other salt-affected areas with a similar soil type. The soil profile at each site was described and classified to confirm that the two sites were covered by the same reference soil group. With respect to land use, one was arable land (SnA, used for maize production) and the other was pasture land ( $\mathrm{SnP}$, with grassy vegetation). The hypothesis was that significant differences in terms of microbiological and chemical properties should be observed between the two sites due to the land use system. It was also expected that the use of fertilizer on the arable site $(\mathrm{SnA})$ would result in higher nutrient contents in comparison to the pasture site $(\mathrm{SnP})$, which could decrease the microbiological activity on the arable site (SnA). High moisture content and organic carbon content were expected on the $\mathrm{SnP}$ site. It was also assumed that, due to cultivation, no great differences in microbiological and chemical properties would be observed amongst the plots at the SnA site, while great differences would be expected amongst those at the SnP site, where the values of microbiological properties were expected to be favourable.

\section{Materials and methods}

\section{Study sites}

The research was carried out in the vicinity of Nádudvar (Hajdú-Bihar County, Hungary) at two sites with Solonetz soils. The two representative soil profiles were excavated, sampled, described and classified using international standards (FAO, 2006; IUSS WORKING GROUP WRB, 2015). The ploughed arable site (SnA) had an elevation of $83 \mathrm{~m}$ above sea level and the geographical coordinates were $\mathrm{N}$ $47.458999^{\circ}$ and $\mathrm{E} 21.195950^{\circ}$. This site was ploughed to a depth of $30 \mathrm{~cm}$ and 400 $\mathrm{kg} \mathrm{ha}^{-1}$ NPK (18:7:7) fertilizer was applied to the maize crop. The non-ploughed pasture site (SnP) had an elevation of $85 \mathrm{~m}$ above sea level and the geographical coordinates were $\mathrm{N} 47.468497^{\circ}$ and E 21.172774. The site has not been cultivated for more than 30 years.

Soil samples were collected from a depth of $0-15 \mathrm{~cm}$ on eight $100 \mathrm{~m}^{2}(10$ $\mathrm{m} * 10 \mathrm{~m}$ ) plots at each site (SnA and SnP) in June 2016. Ten soil subsamples were randomly collected from each plot and combined to make a well mixed composite sample. In total, eight composite soil samples were collected (within a $60 \mathrm{~m}$ radius of the soil profile) from each site (Figure 1). 


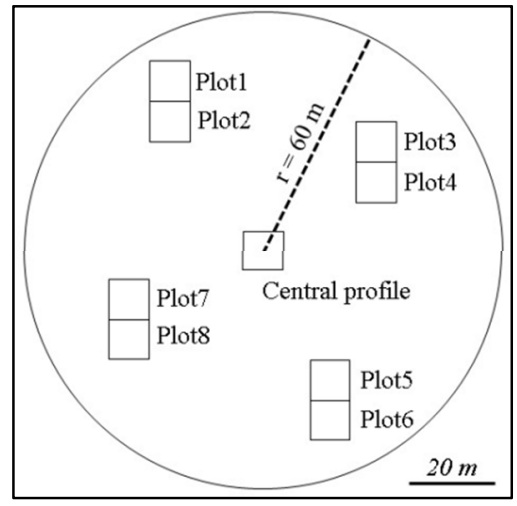

Figure 1

Schematic figure of plots and soil profile within the sampling sites ( $\mathrm{SnA}$ and $\mathrm{SnP}$ ).

Chemical and biological analyses of the soils

The samples were sieved $(<2 \mathrm{~mm})$ to obtain well homogenized samples, stored at $-20^{\circ} \mathrm{C}$ and then transferred to $4^{\circ} \mathrm{C}$ before analysis for microbiological properties. For chemical analysis the soils were air dried and stored at room temperature. All the analyses were done in triplicate. Besides the basic chemical parameters, selected microbiological parameters were investigated to collect a complex database and therefore obtain more detailed information about the processes taking place in the soils.

Soil $\mathrm{pH}$ was measured in a soil:water suspension (1:2.5) and electric conductivity (EC) was measured in $\mathrm{K}_{\mathrm{A}}$ paste according to BUZÁs (1988). Soil organic carbon (OC, \%) was determined by the Walkley-Black method (WALKLEY \& BLACK, 1934). Humic material (E4/E6) was determined by the method given by PAGE et al. (1982). Ammonium $\left(\mathrm{NH}_{4}-\mathrm{N}\right)$ and nitrate $\left(\mathrm{NO}_{3}-\mathrm{N}\right)$ nitrogen were determined from $\mathrm{CaCl}_{2}$ extract (KANDELER, 1996), while AL (ammonium lactate)$\mathrm{P}_{2} \mathrm{O}_{5}, \mathrm{AL}-\mathrm{K}_{2} \mathrm{O}$, magnesium $\left(\mathrm{Mg}^{2+}\right)$, calcium $\left(\mathrm{Ca}^{2+}\right)$ and sodium $\left(\mathrm{Na}^{+}\right)$were extracted according to EGNER et al. (1960). Soil moisture content was determined using the gravimetric method (BUZÁs, 1993).

Soil microbial biomass carbon (MBC) was estimated with the chloroform fumigation-extraction method (VANCE et al., 1987; BROOKES et al., 1985). Basal soil respiration (BSR) was measured as the $\mathrm{CO}_{2}$ evolved at optimum water content (60\% field capacity) (CARTER, 1993; CHENG et al., 2013). The activity of the alkaline phosphatase enzyme was measured as described by TABATABAI \& BREMNER (1969). Dehydrogenase activity (DHA) was determined from the transformation of 2,3,5-triphenyl tetrazolium chloride (TTC) to 1,2,5-triphenyl formazan (TPF) (CASIDA et al., 1964).

Soil profile: Samples from different layers of the profiles were sieved $(<2$ $\mathrm{mm}$ ), air dried and stored for chemical and physical analysis. The above-mentioned methods were used for the chemical analysis of organic carbon (OC), EC and $\mathrm{pH}$, whereas cation exchange capacity (CEC) and exchangeable basic cations ( $\mathrm{S}$ value) 
were determined based on the Mehlich method (MEHLICH, 1953). The exchangeable sodium percentage (ESP \%) was calculated as exchangeable $\mathrm{Na} / \mathrm{CEC} * 100$ (USDA 1954). The $\mathrm{CaCO}_{3}$ content was measured with the Scheibler gas-volumetric method (BUZÁS, 1988), while particle size analysis was conducted using the pipette method (BUZÁs, 1993).

\section{Statistical analysis}

Basic descriptive statistical parameters were calculated from all the measured parameters of all the sampled composite plots (i.e. min, max, mean). The two sites were compared using the T-test for independent samples at the 0.01 and 0.05 significance levels. The differences within each plot were determined by one-way ANOVA using Tukey's HSD post hoc test at the $\mathrm{p}<0.05$ level. Pearson's correlation coefficients were calculated to determine correlations between the microbiological and chemical variables (SPSS statistics vs. 23.0.). All the composite samples were used for principal component analysis (PCA) at the $\mathrm{p}<0.05$ level (PAST vs. 3).

\section{Results}

\section{Site characterization}

Based on the field investigations and laboratory analyses the two profiles were classified as Solonetz soils. In the case of the SnA site (Table 1), the soil was Mollic SOLONETZ (Cutanic, Endoloamic, Hypernatric, Endoprotosalic, Episiltic, Endoprotovertic, Bathiprotocalcic, Bathigleyic).

\section{Table 1}

Representative soil profile data for the Solonetz arable (SnA) site

\begin{tabular}{|c|c|c|c|c|c|c|c|c|c|c|c|c|c|}
\hline \multirow{2}{*}{$\begin{array}{l}\text { Master } \\
\text { horizon }\end{array}$} & Depth & $\mathrm{pH}_{\mathrm{H} 2 \mathrm{O}}$ & $\begin{array}{c}\mathrm{Ca} \\
\mathrm{CO}_{3} \\
\end{array}$ & SOM & Sand & Clay & $a^{2+}$ & $\mathrm{Mg}^{2+}$ & $\mathrm{Na}^{+}$ & $\mathrm{K}^{+}$ & \multirow{2}{*}{$\begin{array}{c}\mathrm{CEC} \\
\mathrm{cmol}^{+} \\
\mathrm{kg}^{-1} \\
\end{array}$} & ESP & \multirow{2}{*}{\begin{tabular}{|c|}
$\begin{array}{c}\text { Salt } \\
\text { cont. }\end{array}$ \\
$\%$
\end{tabular}} \\
\hline & $\mathrm{cm}$ & & $\%$ & $\%$ & $\%$ & $\%$ & \multicolumn{4}{|c|}{$\mathrm{cmol}^{+} \mathrm{kg}^{-1}$} & & $\%$ & \\
\hline Ap1 & & 7. & $<0.1$ & & & & 17 & & 1 & 1.5 & 26.8 & 4.2 & 0.07 \\
\hline $\mathrm{Ap} 2$ & & & 0.3 & & 10 & & & & & & 27.9 & & .08 \\
\hline Bthng & & & 0.2 & & & & & & & 0.5 & 35.1 & 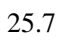 & 2 \\
\hline 2Bthing & & & 0.6 & & & & & & 0 & 0.3 & 0.2 & & 0.32 \\
\hline $3 \mathrm{BCl}$ & & & $<0.1$ & & & & & & 2 & 0.3 & 27.4 & & 0.35 \\
\hline $3 \mathrm{Ckl}$ & - -150 & 9.5 & 10.2 & 0.40 & 0.90 & 35.71 & 10.9 & 5 & 11.9 & 0. & 28.3 & 42.0 & 0.29 \\
\hline
\end{tabular}

In the case of the SnP site (Table 2) the soil was Katocalcic Salic SOLONETZ (Epiclayic, Endoloamic, Cutanic, Humic). 
Table 2

Representative soil profile data for the Solonetz pasture ( $\mathrm{SnP})$ site

\begin{tabular}{|c|c|c|c|c|c|c|c|c|c|c|c|c|c|}
\hline \multirow{2}{*}{$\begin{array}{l}\text { Master } \\
\text { horizon }\end{array}$} & Depth & $\mathrm{pH}_{\mathrm{H} 2 \mathrm{O}}$ & $\mathrm{CaCO}_{3}$ & SOM & Sand & Clay & $\mathrm{Ca}^{2+}$ & $\mathrm{Mg}^{2+}$ & $\mathrm{Na}^{+}$ & $\mathrm{K}^{+}$ & \multirow{2}{*}{$\begin{array}{c}\text { CEC } \\
\mathrm{cmol}^{+} \mathrm{kg}^{-1} \\
\end{array}$} & \multirow{2}{*}{\begin{tabular}{|c|} 
ESP \\
$\%$ \\
\end{tabular}} & \multirow{2}{*}{$\begin{array}{c}\begin{array}{r}\text { Salt } \\
\text { cont }\end{array} \\
\% \\
\end{array}$} \\
\hline & $\mathrm{cm}$ & & $\%$ & $\%$ & $\%$ & $\%$ & \multicolumn{4}{|c|}{$\mathrm{cmol}^{+} \mathrm{kg}^{-1}$} & & & \\
\hline $\mathrm{Oi}$ & $-2-0$ & na & na & na & na & na & na & na & na & na & na & na & na \\
\hline A & $0-5$ & 5.9 & 1.9 & 3.45 & 12.05 & 15.23 & 6.8 & 2.2 & 3.6 & 0.2 & 15.3 & 23.6 & 0.10 \\
\hline Btng & 5-15 & 7.7 & $<0.1$ & 0.95 & 7.84 & 42.54 & 7.2 & 5.3 & 13.4 & 0.6 & 30.8 & 43.4 & 0.35 \\
\hline Bthng & $15-40$ & 9.2 & $<0.1$ & 0.84 & 4.96 & 45.07 & 10.3 & 5.2 & 14.5 & 0.7 & 32.6 & 44.5 & 0.61 \\
\hline Bthkn & $40-55$ & 9.7 & 18.3 & 0.51 & 7.36 & 40.16 & 9.0 & 6.2 & 21.1 & 0.6 & 37.3 & 56.4 & 0.88 \\
\hline $\mathrm{BCk}$ & $55-100$ & 10.1 & 19.9 & 0.40 & 5.73 & 35.63 & 11.2 & 4.6 & 18.2 & 0.3 & 34.3 & 53.2 & 0.90 \\
\hline $\mathrm{Ck}$ & $100-120$ & 10.2 & 15.2 & 0.23 & 10.23 & 30.96 & 9.8 & 4.8 & 17.5 & 0.3 & 32.4 & 54.1 & 0.86 \\
\hline
\end{tabular}

na $=$ not available

\section{Microbiological and chemical characterization of the two sites}

The basic statistical parameters (minimum, maximum and mean with standard deviation) for soil samples taken at a depth of $0-15 \mathrm{~cm}$ at the two sites and the results of the t-test for independent samples can be seen in Table 3 .

Higher microbiological values were recorded on the SnP plots than on the SnA

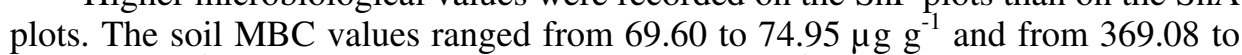
$949.62 \mu \mathrm{g} \mathrm{g}^{-1}$, BSR values from 1.2 to $8.2 \mu \mathrm{g} \mathrm{CO}_{2} \mathrm{~g}^{-1}$ soil h${ }^{-1}$ and from 4.4 to 15.3 $\mu \mathrm{g} \mathrm{CO}_{2} \mathrm{~g}^{-1}$ soil $\mathrm{h}^{-1}$, DHA values from 54.7 to $148.77 \mu \mathrm{g}$ formazan $\mathrm{g}^{-1}$ day $^{-1}$ and from 198.72 to $575.59 \mu \mathrm{g}$ formazan $\mathrm{g}^{-1} \mathrm{day}^{-1}$ and phosphatase activity from 0.044 to $0.148 \mu \mathrm{mol} \mathrm{PNP} \mathrm{g}{ }^{-1} \mathrm{~h}^{-1}$ and from 0.064 to $0.263 \mu \mathrm{mol} \mathrm{PNP} \mathrm{g}^{-1} \mathrm{~h}^{-1}$ at the SnA and $\mathrm{SnP}$ sites, respectively. The values of OC and E4/E6 were also higher for SnP, ranging from 4.84 to $6.96 \%$ and from 4.44 to $5.14 \%$, respectively (Table 3).

Among the chemical properties, $\mathrm{pH}$ and $\mathrm{EC}$ were higher at the ploughed $\mathrm{SnA}$ site (Table 3). Soil $\mathrm{pH}$ values ranged from 6.10 to 7.8 for $\mathrm{SnA}$ and from 5.1 to 6.2 for $\mathrm{SnP}$, while soils collected from both sites showed a distinct variation in soil EC values, which ranged from 255 to $480 \mu \mathrm{S} \mathrm{cm}^{-1}$ for $\mathrm{SnA}$ and from 139 to $377 \mu \mathrm{S} \mathrm{cm}$ ${ }^{1}$ for $\mathrm{SnP}$. The concentration of $\mathrm{K}_{2} \mathrm{O}$ varied from 256 to $490 \mathrm{mg} \mathrm{kg}^{-1}$ and from 100 to $296 \mathrm{mg} \mathrm{kg}^{-1}$, that of $\mathrm{Mg}^{+}$from 34.9 to $74.6 \mathrm{mg} \mathrm{kg}^{-1}$ and from 26.4 to $41.3 \mathrm{mg} \mathrm{kg}$ ${ }^{1}$, that of $\mathrm{Ca}^{+}$from 768 to $1666 \mathrm{mg} \mathrm{kg}^{-1}$ and from 436 to $846 \mathrm{mg} \mathrm{kg}^{-1}$ and that of $\mathrm{Na}^{+}$from 114 to $630 \mathrm{mg} \mathrm{kg}^{-1}$ and from 128 to $626 \mathrm{mg} \mathrm{kg}^{-1}$ at the SnA and SnP sites, respectively. The $\mathrm{P}_{2} \mathrm{O}_{5}$ concentration varied from 322 to $1479 \mathrm{mg} \mathrm{kg}^{-1}$ and from 130 to $371 \mathrm{mg} \mathrm{kg}^{-1}$ for SnA and $\mathrm{SnP}$. The values of $\mathrm{NH}_{4}-\mathrm{N}$ were higher for $\mathrm{SnP}$, with a mean of $8.77 \mathrm{mg} \mathrm{kg}^{-1}$ compared to $4.22 \mathrm{mg} \mathrm{kg}^{-1}$ for $\mathrm{SnA}$, while the values of $\mathrm{NO}_{3^{-}}$ $\mathrm{N}$ were higher for SnA, with a mean of $39.03 \mathrm{mg} \mathrm{kg}^{-1}$ compared to $3.78 \mathrm{mg} \mathrm{kg}^{-1}$ for SnP. 
Table 3

Descriptive statistics and the results of t-tests for independent samples for the two sampling sites $(\mathrm{n}=8$ for each site; depth $0-15 \mathrm{~cm})$

\begin{tabular}{|c|c|c|c|c|c|c|c|c|}
\hline \multirow{2}{*}{ Property } & \multirow{2}{*}{ Unit } & \multicolumn{3}{|c|}{ SnA } & \multicolumn{3}{|c|}{ SnP } & \multirow{2}{*}{$\begin{array}{l}\text { Sig. 2- } \\
\text { tailed }\end{array}$} \\
\hline & & $\min$ & $\max$ & $\operatorname{mean}(\mathrm{SD})$ & $\min$ & $\max$ & mean(SD) & \\
\hline $\begin{array}{l}\text { Basal soil } \\
\text { respiration }\end{array}$ & $\begin{array}{c}\left(\mu \mathrm{g} \mathrm{CO}_{2}\right. \\
\left.\mathrm{g}^{-1} \text { soil h}^{-1}\right)\end{array}$ & 1.20 & 8.20 & $5.12(2.15)$ & 4.40 & 15.30 & $9.71(2.48)$ & $\begin{array}{c}0.000 \\
* *\end{array}$ \\
\hline $\begin{array}{l}\text { Microbial } \\
\text { biomass } \\
\text { carbon }\end{array}$ & $\left(\mu \mathrm{g} \mathrm{g}^{-1}\right)$ & 69.60 & 74.95 & 73.74 (1.14) & 369.08 & 949.36 & $\begin{array}{c}575.64 \\
(180.64)\end{array}$ & $\begin{array}{l}0.000 \\
* *\end{array}$ \\
\hline $\begin{array}{l}\text { Dehydrogen- } \\
\text { ase activity }\end{array}$ & $\begin{array}{c}(\mu \mathrm{g} \\
\text { formazan } \\
\left.\mathrm{g}^{-1} \text { day }^{-1}\right)\end{array}$ & 54.70 & 148.77 & $\begin{array}{l}103.26 \\
(31.91)\end{array}$ & 198.72 & 575.59 & $\begin{array}{c}332.76 \\
(109.11)\end{array}$ & $\begin{array}{l}0.000 \\
* *\end{array}$ \\
\hline $\begin{array}{c}\text { Alkaline } \\
\text { phosphatase } \\
\text { activity }\end{array}$ & $\begin{array}{c}(\mu \mathrm{mol} \\
\mathrm{PNP}^{-1} \\
\left.\mathrm{~h}^{-1}\right)\end{array}$ & 0.044 & 0.148 & $0.107(0.03)$ & 0.064 & 0.263 & $0.161(0.08)$ & $0.003 *$ \\
\hline $\begin{array}{l}\text { Organic } \\
\text { carbon }\end{array}$ & $(\%)$ & 3.03 & 4.32 & $3.83(0.38)$ & 4.84 & 6.96 & $5.52(0.63)$ & $\begin{array}{c}0.000 \\
* *\end{array}$ \\
\hline E4/E6 & & 3.94 & 4.28 & $4.11(0.10)$ & 4.44 & 5.14 & $4.71(0.18)$ & $\begin{array}{c}0.000 \\
* *\end{array}$ \\
\hline pH & & 6.10 & 7.80 & $6.77(0.55)$ & 5.10 & 6.20 & $5.55(0.35)$ & $\begin{array}{c}0.000 \\
* *\end{array}$ \\
\hline $\begin{array}{c}\text { Electrical } \\
\text { conductivity }\end{array}$ & $\left(\mu \mathrm{S} \mathrm{cm}^{-1}\right)$ & 255 & 480 & $\begin{array}{l}358.29 \\
(65.18)\end{array}$ & 139 & 377 & $\begin{array}{l}224.71 \\
(67.70)\end{array}$ & $\begin{array}{c}0.000 \\
* *\end{array}$ \\
\hline $\mathbf{N H}_{4}-\mathbf{N}$ & $\left(\mathrm{mg} \mathrm{kg}^{-1}\right)$ & 2.2 & 6.1 & $4.42(1.26)$ & 6.0 & 13.0 & $8.77(2.46)$ & $\begin{array}{c}0.000 \\
* *\end{array}$ \\
\hline $\mathrm{NO}_{3}-\mathrm{N}$ & $\left(\mathrm{mg} \mathrm{kg}^{-1}\right)$ & 23.6 & 49.3 & $39.03(9.65)$ & 1.4 & 7.0 & $3.78(2.05)$ & $\begin{array}{c}0.000 \\
* *\end{array}$ \\
\hline $\mathbf{P}_{2} \mathbf{O}_{5}$ & $\left(\mathrm{mg} \mathrm{kg}^{-1}\right)$ & 322 & 1479 & $\begin{array}{c}671.71 \\
(273.88) \\
\end{array}$ & 130 & 371 & $\begin{array}{l}233.67 \\
(69.99)\end{array}$ & $\begin{array}{l}0.000 \\
* *\end{array}$ \\
\hline $\mathbf{K}_{2} \mathbf{O}$ & $\left(\mathrm{mg} \mathrm{kg}^{-1}\right)$ & 256 & 490 & $\begin{array}{l}383.42 \\
(59.32)\end{array}$ & 100 & 296 & $\begin{array}{l}177.25 \\
(62.51)\end{array}$ & $\begin{array}{c}0.000 \\
* *\end{array}$ \\
\hline $\mathrm{Mg}^{2+}$ & $\left(\mathrm{mg} \mathrm{kg}^{-1}\right)$ & 34.9 & 72.6 & $44.07(9.81)$ & 26.4 & 41.3 & $32.63(4.13)$ & $\begin{array}{c}0.000 \\
* *\end{array}$ \\
\hline $\mathrm{Ca}^{2+}$ & $\left(\mathrm{mg} \mathrm{kg}^{-1}\right)$ & 768 & 1666 & $\begin{array}{l}1075.63 \\
(216.56)\end{array}$ & 436 & 846 & $\begin{array}{l}606.38 \\
(99.17)\end{array}$ & $\begin{array}{c}0.000 \\
* *\end{array}$ \\
\hline $\mathrm{Na}^{+}$ & $\left(\mathrm{mg} \mathrm{kg}^{-1}\right)$ & 114 & 630 & $\begin{array}{c}288.83 \\
(181.74) \\
\end{array}$ & 128 & 626 & $\begin{array}{c}279.83 \\
(130.49) \\
\end{array}$ & 0.845 \\
\hline Soil moisture & $(\%)$ & 19.94 & 23.27 & $21.72(0.89)$ & 18.54 & 24.66 & $21.27(1.69)$ & 0.258 \\
\hline
\end{tabular}

***: Significantly different at the 0.05 and 0.01 levels, respectively

\section{Soil microbial activity in salt-affected soils}

Table 4 shows the results obtained for the upper $15 \mathrm{~cm}$ soil layer of each plot at the two sampling sites, $\mathrm{SnA}$ and $\mathrm{SnP}$. The data revealed that soil microbial activity was greatly influenced by the land use system. Great heterogeneity was observed for the microbiological properties of the pasture site $(\mathrm{SnP})$. This heterogeneity was decreased by the soil cultivation on arable land. At the two sites, the highest value of MBC was recorded for SnP-8 $\left(897.64 \mu \mathrm{g} \mathrm{g}^{-1}\right)$ and the lowest for SnA-5 $\left(71.38 \mu \mathrm{g} \mathrm{g}^{-1}\right)$. Similarly, DHA was the highest for SnP-8 $(575.57 \mu \mathrm{g}$ formazan $\mathrm{g}^{-1}$ day $\left.^{-1}\right)$ and the lowest for SnA-4 (71.61 $\mu$ g formazan $\mathrm{g}^{-1}$ day $\left.{ }^{-1}\right)$. The 
values of MBC and DHA were lower in all plots for SnA than for SnP. The BSR values were higher for $\mathrm{SnP}$ (5.51 to $12.87 \mu \mathrm{g} \mathrm{CO}_{2} \mathrm{~g}^{-1}$ soil h${ }^{-1}$ ) than for $\mathrm{SnA}$ (1.54 to $7.61 \mu \mathrm{g} \mathrm{CO}_{2} \mathrm{~g}^{-1}$ soil $\left.\mathrm{h}^{-1}\right)$. The phosphatase acitvity was the highest for SnP-6 $(0.263$ $\left.\mu \mathrm{mol} \mathrm{PNP} \mathrm{g} \mathrm{h}^{-1}\right)$ and the lowest for SnA-5 $\left(0.044 \mu \mathrm{mol} \mathrm{PNP} \mathrm{g}{ }^{-1} \mathrm{~h}^{-1}\right)$.

\section{Table 4}

Microbiological properties of the $0-15 \mathrm{~cm}$ layer of the two sites ( $\mathrm{SnA}$ and $\mathrm{SnP}$ ) (means with SD in brackets) and the results of Tukey's test for individual sampling plots (1-8) within each sampling site. Letters indicate significant differences between the parameters for each plot ( $\mathrm{n}=3$ for each plot).

\begin{tabular}{|c|c|c|c|c|}
\hline \multirow{2}{*}{ Plot No. } & $\begin{array}{c}\text { Basal soil } \\
\text { respiration }\end{array}$ & $\begin{array}{c}\text { Microbial } \\
\text { biomass } \\
\text { carbon }\end{array}$ & $\begin{array}{c}\text { Dehydrogenase } \\
\text { activity }\end{array}$ & $\begin{array}{c}\text { Alkaline } \\
\text { phosphatase } \\
\text { activity }\end{array}$ \\
\cline { 2 - 5 } & $\begin{array}{c}\left(\mu \mathrm{g} \mathrm{CO}_{2} \mathrm{~g}^{-1}\right. \\
\left.\text { soil }^{-1}\right)\end{array}$ & $\left(\mu \mathrm{g} \mathrm{g}^{-1}\right)$ & $\begin{array}{c}\left(\mu \mathrm{g}^{-1} \mathrm{~g}^{-1} \mathrm{day}^{-1}\right) \\
\left(\mu \mathrm{mol}^{-1} \mathrm{PNP} \mathrm{g}^{-1}\right)\end{array}$ \\
\hline SnA-1 & $7.61(0.55) \mathrm{de}$ & $74.25(0.60) \mathrm{a}$ & $78.99(0.17) \mathrm{c}$ & $0.123\left(1 \times 10^{-4}\right) \mathrm{j}$ \\
\hline SnA-2 & $5.59(0.48) \mathrm{bcd}$ & $73.78(0.28) \mathrm{a}$ & $54.72(0.03) \mathrm{a}$ & $0.130\left(2.3 \times 10^{-4}\right) \mathrm{k}$ \\
\hline SnA-3 & $2.66(0.32) \mathrm{ab}$ & $74.09(0.41) \mathrm{a}$ & $148.60(0.15) \mathrm{h}$ & $0.148\left(0.9 \times 10^{-4}\right) \mathrm{l}$ \\
\hline SnA-4 & $7.33(0.39) \mathrm{de}$ & $74.23(0.46) \mathrm{a}$ & $71.61(0.38) \mathrm{b}$ & $0.093\left(1.2 \times 10^{-4}\right) \mathrm{d}$ \\
\hline SnA-5 & $6.69(0.55) \mathrm{cd}$ & $71.38(1.99) \mathrm{a}$ & $96.82(0.01) \mathrm{d}$ & $0.044\left(0.8 \times 10^{-4}\right) \mathrm{a}$ \\
\hline SnA-6 & $1.54(0.31) \mathrm{a}$ & $74.02(0.39) \mathrm{a}$ & $125.42(0.06) \mathrm{f}$ & $0.101\left(0.4 \times 10^{-4}\right) \mathrm{g}$ \\
\hline SnA-7 & $5.53(0.83) \mathrm{bcd}$ & $73.77(0.13) \mathrm{a}$ & $112.08(0.05) \mathrm{e}$ & $0.094\left(1.9 \times 10^{-4}\right) \mathrm{e}$ \\
\hline SnA-8 & $3.97(0.58) \mathrm{abc}$ & $74.36(0.05) \mathrm{a}$ & $137.84(0.13) \mathrm{g}$ & $0.122\left(0.9 \times 10^{-4}\right) \mathrm{i}$ \\
\hline SnP-1 & $5.51(1.13) \mathrm{bcd}$ & $370.09(0.87) \mathrm{b}$ & $303.23(0.00) \mathrm{k}$ & $0.196\left(0.1 \times 10^{-4}\right) \mathrm{m}$ \\
\hline SnP-2 & $10.01(1.56) \mathrm{efg}$ & $443.49(73.74) \mathrm{b}$ & $229.78(0.02) \mathrm{j}$ & $0.220\left(1.4 \times 10^{-4}\right) \mathrm{n}$ \\
\hline SnP-3 & $8.25(0.64) \mathrm{def}$ & $418.10(42.45) \mathrm{b}$ & $198.74(0.02) \mathrm{i}$ & $0.987\left(0.5 \times 10^{-4}\right) \mathrm{f}$ \\
\hline SnP-4 & $8.16(0.24) \mathrm{def}$ & $663.28(73.85) \mathrm{c}$ & $319.79(0.15) \mathrm{m}$ & $0.263\left(2.3 \times 10^{-4}\right) \mathrm{p}$ \\
\hline SnP-5 & $10.16(1.20) \mathrm{efg}$ & $441.66(0.55) \mathrm{b}$ & $378.54(0.06) \mathrm{o}$ & $0.110\left(0.3 \times 10^{-4}\right) \mathrm{h}$ \\
\hline SnP-6 & $12.87(2.31) \mathrm{g}$ & $686.61(41.74) \mathrm{c}$ & $345.02(0.72) \mathrm{n}$ & $0.252\left(0.5 \times 10^{-4}\right) \mathrm{o}$ \\
\hline SnP-7 & $11.73(1.56) \mathrm{g}$ & $684.25(42.50) \mathrm{c}$ & $311.39(0.28) \mathrm{l}$ & $0.088\left(0.9 \times 10^{-4}\right) \mathrm{c}$ \\
\hline SnP-8 & $11.03(0.14) \mathrm{fg}$ & $897.64(45.67) \mathrm{d}$ & $575.57(0.03) \mathrm{p}$ & $0.064\left(0.6 \times 10^{-4}\right) \mathrm{b}$ \\
\hline
\end{tabular}

Letters a-p indicate significant differences between means according to Tukey's test $(\mathrm{p}<5)$

Table 5 shows that BSR and DHA were positively correlated with MBC, whereas the phosphatase activity showed no correlation with the other microbiological properties. BSR, MBC and DHA were positively correlated with $\mathrm{OC}$ and E4/E6 and negatively correlated with $\mathrm{pH}$ and EC. A strong negative correlation was also found between microbiological properties (BSR, MBC and DHA) and $\mathrm{NO}_{3}-\mathrm{N}, \mathrm{K}_{2} \mathrm{O}$ and $\mathrm{Ca}^{2+}$, while, $\mathrm{P}_{2} \mathrm{O}_{5}$ showed a negative correlation with $\mathrm{MBC}$ and DHA. 
Table 5

Correlation matrix of the chemical and microbiological soil properties $(n=16)$.

\begin{tabular}{|c|c|c|c|c|}
\hline & $\begin{array}{l}\text { Basal soil } \\
\text { respiration }\end{array}$ & $\begin{array}{l}\text { Microbial biomass } \\
\text { carbon }\end{array}$ & $\begin{array}{l}\text { Dehydrogenase } \\
\text { activity }\end{array}$ & $\begin{array}{l}\text { Alkaline } \\
\text { phosphatase } \\
\text { activity }\end{array}$ \\
\hline $\begin{array}{l}\text { Microbial biomass } \\
\text { carbon }\end{array}$ & $0.758 * *$ & & & \\
\hline $\begin{array}{l}\text { Dehydrogenase } \\
\text { activity }\end{array}$ & $0.622 * *$ & $0.916 * *$ & & \\
\hline $\begin{array}{l}\text { Alkaline } \\
\text { phosphatase } \\
\text { activity }\end{array}$ & 0.189 & $0.322 *$ & 0.201 & \\
\hline Organic carbon & $0.553 * *$ & $0.854 * *$ & $0.866 * *$ & 0.191 \\
\hline E4/E6 & $0.669 * *$ & $0.931 * *$ & $0.894 * *$ & 0.241 \\
\hline $\mathrm{pH}$ & $-0.615^{* *}$ & $-0.829 * *$ & $-0.764 * *$ & -0.190 \\
\hline $\begin{array}{l}\text { Electrical } \\
\text { conductivity }\end{array}$ & $-0.672 * *$ & $-0.806 * *$ & $-0.681 * *$ & -0.135 \\
\hline $\mathrm{NH}_{4}-\mathrm{N}$ & $0.369 * *$ & $0.529 * *$ & $0.488 * *$ & $0.317 *$ \\
\hline $\mathrm{NO}_{3}-\mathrm{N}$ & $-0.696^{* *}$ & $-0.850 * *$ & $-0.778^{* *}$ & $-0.341 *$ \\
\hline $\mathrm{P}_{2} \mathrm{O}_{5}$ & $-0.479 * *$ & $-0.716^{* *}$ & $-0.690 * *$ & -0.180 \\
\hline $\mathrm{K}_{2} \mathrm{O}$ & $-0.647 * *$ & $-0.833^{* *}$ & $-0.791^{* *}$ & -0.154 \\
\hline $\mathrm{Mg}^{2+}$ & $-0.609 * *$ & $-0.525 * *$ & $-0.471 * *$ & $-0.291 *$ \\
\hline $\mathrm{Ca}^{2+}$ & $-0.663^{* *}$ & $-0.779 * *$ & $-0.696 * *$ & $-0.315^{*}$ \\
\hline $\mathrm{Na}^{+}$ & -0.175 & -0.184 & -0.115 & 0.189 \\
\hline Soil moisture & $-0.443 * *$ & -0.261 & $-0.301 *$ & $0.361 *$ \\
\hline
\end{tabular}

Pearson's correlation $\mathrm{p}<0.05$. ***: Significant at the 0.05 and 0.01 levels, respectively.

The results of PCA (Figure 2) showed that the arable and pasture plots formed two well-defined point clouds. PC1 explained $75.34 \%$ of the variance based on MBC and $\mathrm{P}_{2} \mathrm{O}_{5}$, while $\mathrm{PC} 2$ explained $16.30 \%$ of the total variance based on $\mathrm{P}_{2} \mathrm{O}_{5}$, $\mathrm{Ca}^{2+}$ and $\mathrm{Na}^{+}$, so the two sampling sites could be divided by PC1 based on the MBC and $\mathrm{P}_{2} \mathrm{O}_{5}$. 

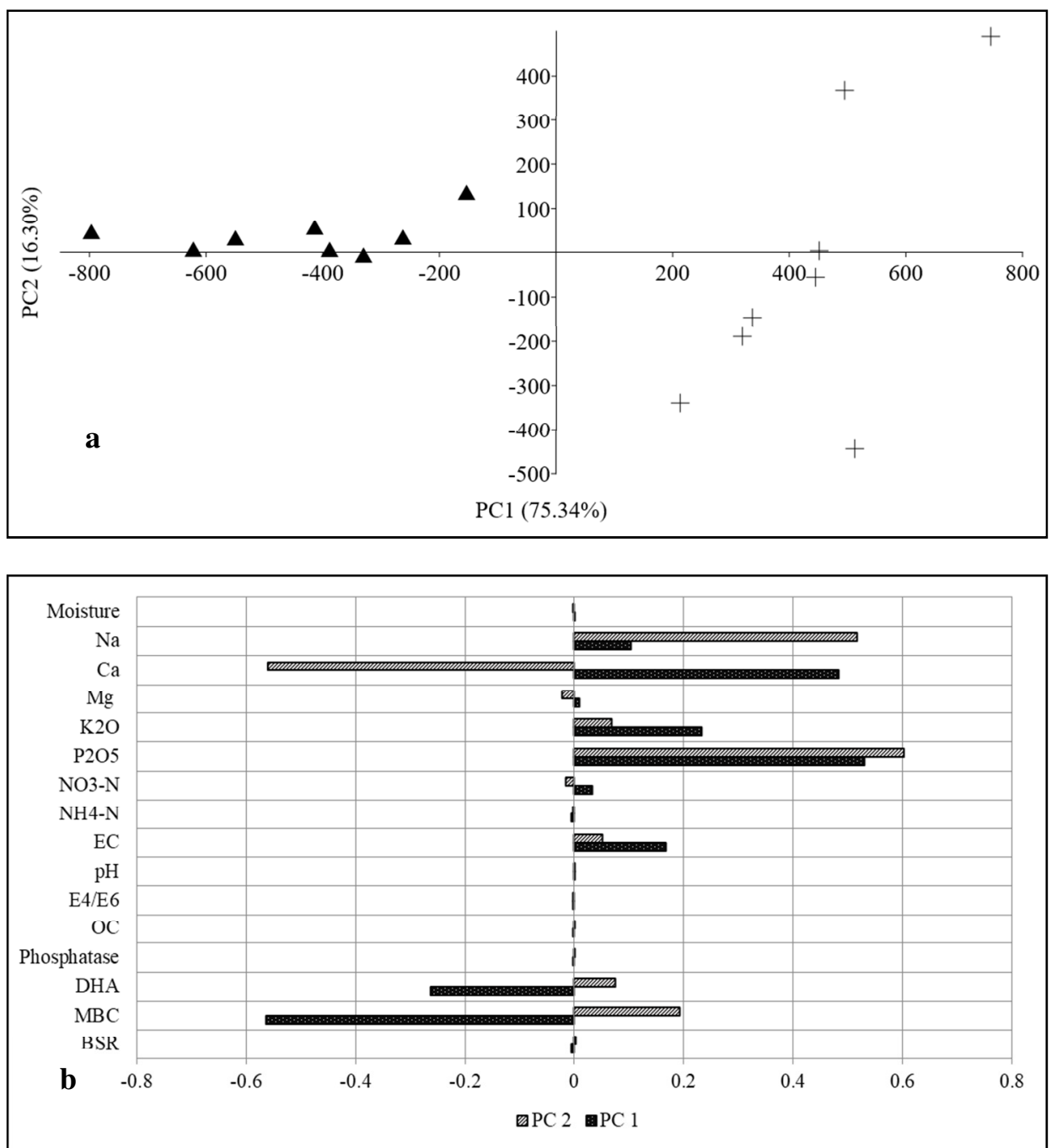

Figure 2

Results of principal component analysis. a: PC factor scores along PC1 and PC2. $\boldsymbol{\Delta}$ SnA; + SnP; b: PC factor loadings of PC1 and PC2

\section{Discussion}

It could be concluded that the two sites were statistically different from each other for all the parameters investigated, except for $\mathrm{Na}$ and moisture content (Table $3)$. Based on the preliminary hypothesis, higher moisture values were expected for SnP, but similar moisture content was observed at both sites, presumably due to the heavy rain that occurred before sampling. In a study performed by ÁBRAHÁM \& GINÁL (1967) no effect on the exchangeable Na content could be detected after 15 
years of cultivation. Due to regular fertilization the nutrient content $\left(\mathrm{NO}_{3}-\mathrm{N}, \mathrm{P}_{2} \mathrm{O}_{5}\right.$, $\mathrm{K}_{2} \mathrm{O}, \mathrm{Mg}^{+}$and $\mathrm{Ca}^{2+}$ ) was higher at the $\mathrm{SnA}$ site. This confirmed the results of ÁBRAHÁM \& GINÁL (1967), who found an increase in $\mathrm{P}_{2} \mathrm{O}_{5}$ on cultivated plots. In the present work there was an increase in $\mathrm{K}_{2} \mathrm{O}$, in contrast to the decrease in $\mathrm{K}_{2} \mathrm{O}$ and total nitrogen reported by ÁBRAHÁM \& GINÁL (1967). $\mathrm{NH}_{4}-\mathrm{N}$ was higher at the SnP site, presumably due to the poorer aeration on the uncultivated grass land. These differences in soil properties between the soils of arable $(\mathrm{SnA})$ and pasture $(\mathrm{SnP})$ sites (Table 3) can be explained by differences in the land use system and by the fertilizers applied at the SnA site.

The soil mean $\mathrm{pH}$ was relatively low (5.55) at the $\mathrm{SnP}$ site, while the microbiological activity (BSR, MBC, DHA and phosphatase) was higher compared to the SnA site. It was hypothesized that ploughing had a more direct influence on microbiological properties than $\mathrm{pH}$ in the case of salt-affected soils, although NEALE et al. (1997) reported that the effect of $\mathrm{pH}$ was found to be one of the most important environmental factors for soil microbes. Non-ploughing and the continuous plant coverage resulted in higher organic matter content at the SnP site, leading to an increase in microbial enzyme activities (TEJADA et al., 2006). ÁBRAHÁM \& GINÁL (1967) reported that after 15 years of ploughing the OM content of the ploughed soil layer of a Solonetz pasture in Hungary decreased by $12-22 \%$. The lower values of phosphatase at the SnA site could be the result of inorganic fertilizer application and higher $\mathrm{pH}$ and EC. SAHA et al. (2008) also reported decreased phosphatase activity after inorganic fertilization and KHALIF et al. (2005) found that phosphatase was sensitive to salt concentration. The values of E4/E6 were lower on the SnA plots, suggesting the higher quality of organic matter. However, E4/E6 values less than 5 were also measured on the SnP plots, indicating that both areas were characterized by humic acids (STEVENSON, 1994).

The higher values of microbiological properties indicated that the nonploughed SnP plots were microbiologically more active. The higher SD values calculated for the microbiological parameters at the $\mathrm{SnP}$ site suggested that the area was more heterogeneous in terms of microbiological activity, presumably due to the greater root mass of the permanent grassy vegetation, while ploughing may have decreased and homogenized the soil microbiological activity at the SnA site (Table $3)$.

Despite the great heterogeneity of the microbiological properties (Table 4), overall, higher values were found in the case of $\mathrm{SnP}$, indicating that this site was biologically more active. The MBC content seemed to be homogeneous on the ploughed SnA plots, whereas this property showed great variance on the SnP plots. Dehydrogenase activity was very heterogeneous, as dehydrogenase is an intracellular enzyme (KANDELER, 2007) and is usually correlated with the microbial biomass. Nevertheless, very variable dehydrogenase activity was associated with similar MBC values at the SnA site, indicating that the species composition or the microbial activity at different points of the SnA site were different. KHALIF et al. (2005) stated that DHA was less sensitive to salt concentration up to $0.4 \% \mathrm{NaCl}$ content than phosphatase activity. The latter was significantly different for each 
sampling plot. No clear tendency could be observed based on the present results. Thus, the phosphatase activity of the SnA and SnP plots could not be distinguished. Different plant species occupy different microhabitats on salt-affected soils according to the local salt content of the soil. FÜZY et al. (2008) found different arbuscular mycorrhizal fungi (AMF) colonization rates for different plant species. The colonization rate also depended on the salt content of the soil. Moreover, heavy rainfall decreased the AMF colonization rate of the roots, while drought increased it.

When relationships between the chemical and microbiological parameters were studied, strong positive correlations were found between most of the microbiological parameters (BSR, MBC and DHA) and OC and E4/E6 (Table 5). The positive correlations with E4/E6 suggest higher microbial biomass and activity, possibly due to greater amounts of more labile organic matter, which might serve as a nutrient source for microbes. High doses of NPK fertilizers could decrease the enzyme activities in the soil (GUANGMING et al., 2017). Similarly, the increase in available macronutrients resulted in strong negative correlations with microbiological properties (BSR, MBC and DHA) except for $\mathrm{NH}_{4}-\mathrm{N}$, which had a significant positive correlation with $\mathrm{MBC}$ and DHA in this study. Moreover, the increase in EC in the soil reduced the activity of alkaline phosphatase and other enzymes (RIETZ \& HAYNES, 2003). The alkaline phosphatase activity was independent of the inorganic $\mathrm{P}_{2} \mathrm{O}_{5}$ concentration in the soil. Similar results were found by TURNER \& HAYGARD (2005), who stated that phosphomonoesterase activity was strongly correlated with organic phosphorus (P) but not with the inorganic $\mathrm{P}$ content. Organic $\mathrm{P}$ is abundant in soils and contributes to the $\mathrm{P}$ nutrition of plants and microbes following hydrolysis and the release of free phosphate (CONDRON et al., 2005).

\section{Conclusions}

This study on salt-affected soils showed that microbial activity was negatively influenced by the land use system and the use of fertilizers on arable land, as indicated by the lower values of MBC, BSR, DHA and phosphatase activity. In terms of microbiological properties, the $\mathrm{SnP}$ site showed great heterogeneity, whereas the SnA site was more homogeneous in terms of microbiological activity. Overall, the land use system had significant effects on the microbiological and chemical properties of salt-affected soils.

\section{Acknowledgements}

The authors are grateful to the Tempus Public Foundation (Government of Hungary) for a doctoral scholarship (Stipendium Hungaricum Scholarship Program) and to Mr. Gábor Mészáros (KITE ZRT), for permission to use the study sites and the cultivation data. 


\section{References}

ÁBRAHÁM L., BoCSKAI, J. 1971. Utilisation and amelioration of saline soils. OMMI. Budapest (In Hungarian)

ARANY S. 1956. Amelioration of saline soils. Mezőgazdasági Kiadó, Budapest (In Hungarian)

Balog K., Gribovszki Z., Szabó A., Jobbágy E., Nosetto, M., Kuti L., PÁszTOR L., TóTH T., 2014. Effect of forest plantations on subsurface salt accumulation in lowlands with shallow groundwater. Agrokémia és Talajtan. 63. (2) 249-268. (In Hungarian)

Balota, E.L., Colozzi-Filho, A., AndRade, D.S., Dick, R.P. 2003. Microbial biomass in soils under different tillage and crop rotation systems. Biology and Fertility of Soils. 38. 15-20.

Bastida, F., Zsolnay, A., Hernández, T., García, C. 2008. Past, present and future of soil quality indices: a biological perspective. Geoderma. 147. 159171.

BAtRA, L., MANNA, M.C. 1997. Dehydrogenase activity and microbial biomass carbon in salt-affected soils of semiarid and arid regions. Arid Soil Research and Rehabilitation. 11. (3) 295-303.

BENDING, G.D., TURNER, M.K., JONES, J.E. 2002. Interactions between crop residue and soil organic matter quality and the functional diversity of soil microbial communities. Soil Biology and Biochemistry. 34. 1073-1082.

BIRÓ, B., VILLÁNYI, I., KÖVES-PÉCHY, K. 2002. Abundance and adaptation level of some microbes in salt-affected soils. Agrokémia és Talajtan. 51 (1-2) 99-106.

Borsodi, A. K., Micsinai, A., RUSZnYÁK, A. ,Vladar, P., Kovacs, G., TOTH, E. M., MARIALIGETI, K. 2005. Diversity of alkaliphilic and alkalitolerant bacteria cultivated from decomposing reed rhizomes in a Hungarian soda lake. Microbial Ecology. 50. 9-18.

Borsodi, A. K., RuSZnYÁK, A., MolnáR, P., VladÁR, P., RESKÓNÉ, M. N., TÓTH, E. M., Sipos, R., GEDEON, G., MÁRIALIGETI, K. 2007. Metabolic activity and phylogenetic diversity of reed (Phragmites australis) periphyton bacterial communities in a Hungarian shallow soda lake. Microbial Ecology. 53 (4) 612-620.

Brookes, P.C., Landman, A., Pruden, G., Jenkinson, D.S. 1985. Chloroform fumigation and the release of soil nitrogen: a rapid direct extraction method for measuring microbial biomass nitrogen in soil. Soil Biology and Biochemistry. 17. $837-842$.

BuZÁs I. 1988. Manual of Soil and Agrochemical Analysis. 2. Physico-chemical and Chemical Analytical methods for soils. Mezőgazdasági Kiadó. Budapest. Hungary. (In Hungarian)

BuZÁs, I. 1993. Manual of Soil and Agrochemical Analysis. 2. Physical, Water management and Mineralogical Analysis of the soil. INDA 4231. Budapest. Hungary. (In Hungarian) 
CARTER, M.R. 1993. Soil Sampling and Methods of Analysis. Lewis Publishers. Toronto.

CASIDA, L.E. JR., Klein, D.A., SAntoro, T. 1964. Soil dehydrogenase activity. Soil Science. 98. 371-376.

Cheng, F., Peng, X., ZhaO, P., Yuan, J., Zhong, C., Cheng, Y., Cui, C., Zhang, S. 2013. Soil microbial biomass, basal respiration and enzyme activity of main forest types in the Qinling Mountains. PLoS One. 8. e67353.

CONDRON, L.M., TURNER, B.L., CADE-MENUN, B.J. 2005. Chemistry and dynamics of soil organic phosphorus. In: SIMS, T., SHARPLEY, A.N. (eds.). Phosphorus: Agriculture and the Environment. American Society of Agronomy Madison (Wisconsin, USA) 7.

EgNER, H., RIEHM, H., DOMINGO, W. 1960. Untersuchungen über die chemische Bodenanalyse als Grundlage für die Beurteilung des Nährstoffzustandes der Böden II. Chemische Extraktionsmethoden zur Phosphor- und Kaliumbestimmung. Kungl. Lantbrukshögsk. Ann. 26. 199-215.

EUROPEAN COMMISSION 2007. Directorate General for Research-Sustainable Development. Global Change and Ecosystems. Catalogue of projects funded during the Sixth Framework. pp. 362-363. European Commission. Brussels. Belgium.

FAO 2006. Guidelines for Soil Description. $4^{\text {th }}$ edition. FAO. Rome.

FelFöldI, T., SOMOGYI, B., MÁRIALIGETI, K., VÖRÖs, L. 2009. Characterization of photoautotrophic picoplankton assemblages in turbid, alkaline lakes of the Carpathian Basin (Central Europe). Journal of Limnology. 68. 385-395.

FÜZY A., BIRó B., TÓTH T. 2003. Correlations between plant-microbe interactions and soil properties on Hungarian saline soils Természetvédelmi Közlemények. 10. 63-69. (In Hungarian)

FÜZY, A., BIRÓ, B., TóTH, T., HILDEBRANDT, U., BOTHE, H. 2008. Drought, but not salinity determines the apparent effectiveness of halophytes colonized by arbuscular mycorrhizal fungi. Journal of Plant Physiology. 165. 1181-1192.

Grover, M., Ali, S.Z., SANDHYA, V., Rasul, A., VenKateswarlu, B. 2011. Role of microorganisms in adaptation of agriculture crops to abiotic stresses. World Journal of Microbiology and Biotechnology. 27. 1231-1240.

Guangming, L., Xuechen, Z., Xiuping, W., Hongbo, S., Jinsong, Y., XianPing, W. 2017. Soil enzymes as indicators of saline soil fertility under various soil amendments. Agriculture, Ecosystems and Environment. 237. 274-279.

Hedo, J., Lucas-Borja, M.E., Wic-Baena, C., Andrés-Abellán, M., DE las HERAS, J. 2015. Experimental site and season over-control the effect of Pinus halepensis in microbiological properties of soils under semiarid and dry conditions. J. Arid Environ. 116. 44-52.

HERKE S. 1949. Amelioration of sodic-saline soils Agrokémia (5-6) 3-17. (In Hungarian)

IUSS Working Group WRB. 2015. World Reference Base for Soil Resources 2014 (updated 2015). World Soil Resources Reports 106. Food and Agriculture Organization (FAO) of the United Nations. Rome 2015. 
IWAI, C.B., OO, A.N., TOPARK-NGARM B. 2012. Soil property and microbial activity in natural salt-affected soils in an alternating wet-dry tropical climate. Geoderma. 189-190. 144-152.

JiNG, Y., LI, Y., NiAN, J., LIN,Y. 2013. Enzymatic activity of different salt-affected soils in Tumochuan Plain. Ecology and Environmental Sciences. 9. 013.

KANDELER, E. 2007. Physiological and biochemical methods for studying soil biota and their functions. In: PAul, E.A. (ed.): Soil Microbiology, Ecology and Biochemistry. Elsevier. p. 72.

KANDELE, E. 1996. Ammonium. In: Schinner, F., ÖHLINGER, R., KANDELER, E., MARghesin, R. (eds.): Methods in Soil Biology. Springer-Verlag. Berlin. Heidelberg. New York. pp. 406-410.

Khalif, A. A., Abdorhim, H., Bayoumi, H., Hosam, A. F., Oldal B., Kecskés M. 2005. Changes in microbe number and enzyme activity in the rhizosphere of dry bean varieties (Phaseolus vulgaris L.) in response to salt stress. Agrokémia és Talajtan. 54. (3-4) 451-464. (In Hungarian)

KuTi L., Tóth T., KeRÉK B., ZÖLD A., SZENTPÉTERY I. 2002. Fluctuation of the groundwater level. and its consequences in the soil-parent materialgroundwater system of a sodic grassland. Agrokémia és Talajtan. 51 (1-2) 253262.

LuCAS-BorJa, M.E., CANDEl, D., Jindo, K., MoReno, J.L., AndrÉs, M., BASTIDA, F. 2011. Soil microbial community structure and activity in monospecific and mixed forest stands under Mediterranean humid conditions. Plant and Soil. 354. 359-370.

Menlich, A. 1953. Determination of $\mathrm{P}, \mathrm{Ca}, \mathrm{Mg}, \mathrm{K}, \mathrm{Na}$ and $\mathrm{NH}_{4}$. North Carolina Department of Agriculture. Agronomic Division. Soil Testing Division. Publication No. 1-53.

Mucsi M., Csontos P., Borsodi A., Krett G., Gazdag O., Szili-Kovács T. 2017. Use of the microrespiration method to analyse the metabolic activity patterns in the soil of four characteristic sodic plant associations. Agrokémia és Talajtan. 66. (1) 165-179. (In Hungarian)

NeAle, S.P., ShaH, Z., ADAMS, W.A., 1997. Changes in microbial biomass and nitrogen turnover in acidic organic soils following liming. Soil Biology and Biochemistry. 29. 1463-1474.

Page, A.L., Miller, R.H., KeEnEy, D.R. (eds.). 1982. Methods of Soil Analysis. Part 2 ( $2^{\text {nd }}$ ed.). Agronomy Monograph 9. ASA and SSSA. Madison. WI. pp. 591-592.

Pouyat, R.V., MCDOnNell, M.J., PicketT, S.T. 1995. Soil characteristics of oak stands along an urban-rural land-use gradient. Journal of Environmental Quality. 24. 516-526.

RIETZ, D.N. \& HAYNES, R.J. 2003. Effects of irrigation-induced salinity and sodicity on soil microbial activity. Soil Biology and Biochemistry. 35. 845854. 
Saha, S., Prakash, V., Kundu, S., Kumar, N., Mina, B.L. 2008. Soil enzymatic activity as affected by long term application of farm yard manure and mineral fertilizer under a rainfed soybean-wheat system in N-W Himalaya. European Journal of Soil Biology. 44. 309-315.

SARdinha, M., MÜller, T., SChMeisky, H., Joergensen, R.G., 2003. Microbial performance in soils along a salinity gradient under acidic conditions. Applied Soil Ecology. 23. (3). 237-244.

SOMOgYI, B., FelföldI, T., VANYOvsZKi, J., ÁGYI, Á., MÁRIALIGETI, K., VÖRÖS, L. 2009. Winter bloom of picoeukaryotes in Hungarian shallow turbid soda pans and the role of light and temperature. Aquatic Ecology. 43. 735-744.

SteVEnson, F. J. 1994. Humus Chemistry $2^{\text {nd }}$ Edition John Wiley \& Sons Inc.

SuMNER, M.E. 2000. Handbook of Soil Science. CRC Press. Boca Raton.

Szabó, G., Borsodi, A., VladÁr, P., CеCh, G., Tóth, E., Boros, E., MÁRIALIGETI, K. 2004. Bacterological analysis of saline lakes in the Kiskunság National Park. Hidrológiai Közlöny. 84. 147-150. (In Hungarian)

SZABOLCS I. \& VÁRALLYAY G. 1978. Limiting factors of soil fertility in Hungary. Agrokémia és Talajtan 27. (1-2) 181-202. (In Hungarian)

SZABOLCS, I. \& JASSÓ, F. 1959. Klassification der Szikböden Ungarns. Agrokémia és Talajtan 8. 281-300. (In Hungarian)

SZENDREI, G. \& TóTH, T. (eds.) 2006. Salt minerals in the topsoil of saline soils in Hungary). Topographia Mineralogica Hungariae 9. Miskolc (In Hungarian)

SZILI-KovÁcs, T., BÁrÁNY, Á., FüZY, A., TAKács, T., KretT, G., KovÁCS, R., BORSODI, A. 2017. Analysis of the microbial metabolic activity patterns and mycorrhizal fungal colonization in the rhizosphere of three soils neighbouring sodic lakes. Agrokémia és Talajtan 66. (1) 149-164. (In Hungarian)

TABATABAI, M.A., BREMNER, J.M. 1969. Use of p-nitrophenyl phosphate for assay of soil phosphatase activity. Soil Biology and Biochemistry. 1. 301-307.

Tejada, M., Garcia, C., Gonzalez, J.L. \& Hernandez, M.T. 2006. Use of organic amendment as a strategy for saline soil remediation: influence on the physical, chemical and biological properties of soil. Soil Biology Biochemistry. 38. 1413-1421.

TótH T., KerTÉSZ M., PÁszTOR L. 1998. New approaches in salinity/sodicity mapping in Hungary. Agrokémia és Talajtan. 47. 76-86.

Tóth T., KUTI L., FóRIzS I., KABOS S. 2001.A sófelhalmozódás tényezőinek változása a hortobágyi "Nyírőlapos" mintaterület talajainál. Agrokémia és Talajtan. 50. (3-4) 409-426.

TótH T., MOLNÁR S., BALOG K., BAKACSI Z. 2015. Leaching processes in saline lakes on the sand ridge of the Danube-Tisza Interfluve: the case of Lake Szappanos. Agrokémia és Talajtan. 64. (1) 73-92. (In Hungarian)

TótH T. \& VÁRALlYAY G. 2001. Variability in the soil of a sample area according to salt accumulation factors. Agrokémia és Talajtan. 50. 19-34. (In Hungarian)

TóTH, E. \& FARKAS, C. 2010. Effect of inter-row cultivation on soil carbon dioxide emission in a peach plantation. Agrokémia és Talajtan. 59. (1) 157-164. 
Tóth, E., FARKAS, C., KoÓs, S., NÉMETH, T. 2009. Effect of tillage on soil carbon dioxide emission. I. Testing a laboratory method on undisturbed soil columns. Agrokémia és Talajtan. 58. (2) 215-226.

Tripathi, S., Kumari, S., Chakraborty, A., Gupta, A., Chakrabarti, K., BANDYAPADHYAY. B.K. 2006. Microbial biomass and its activities in saltaffected coastal soils. Biology and Fertility of Soils. 42. 273-277.

TURNER B.L., HAYGARD, P.M. 2005. Phosphatase activity in temperate pasture soils: Potential regulation of labile organic phosphorus turnover by phosphodiesterase activity. Science of the Total Environment. 344. 27-36.

USDA (United States Department of Agriculture) 1954. Diagnosis and Improvement of Saline and Alkali Soils. Agriculture Handbook No. 60. United States Salinity Laboratory. Riverside. CA.

VANCE, E.D., BROOKES, P.C., JENKINSON, D.S. 1987. An extraction method for measuring soil microbial biomass C. Soil Biology and Biochemistry. 19. 703707.

VÁRALLYAY G. 1999. Salinization / alkalinzation / sodification processes in the Carpathian Basin. Agrokémia és Talajtan. 48. 399-418. (In Hungarian)

WalKLeY, A. \& BlACK, I.A. 1934. An examination of the Degtjareff method for determining soil organic matter and a proposed modification of the chromic acid titration method. Soil Science. 37. (1) 29-38.

YUAN, B., LI, Z., LIU, H., GAO, M., ZHANG, Y. 2007. Microbial biomass and activity in salt-affected soil under arid condition. Applied Soil Ecology. 35. 319-328. 